\title{
Taboo and Euphemism in Kuningan as Local Wisdom to Support Literation
}

\author{
Asep Jejen Jaelani ${ }^{1}$, Ifah Hanifah ${ }^{2}$, Ida Hamidah ${ }^{3}$ \\ ${ }^{123}$ Indonesian Language and Literature Education, Kuningan University \\ \{1asep.jejen.jaelani@uniku.ac.id, ${ }^{2}$ ifah.hanifah@uniku.ac.id, ${ }^{3}$ ida.hamidah@uniku.ac.id\}
}

\begin{abstract}
This article discusses Taboo and Euphemism in Kuningan language as a form of local wisdom. By using ethnographic studies and data collection with various observations and interviews, this article explores the Sundanese language subject which is categorized as taboo and the use of euphemisms in avoiding it. The result is that the taboo subjects in Sundanese are matters related to belief / myth, mention of animal names, mentions related to limbs and sex, and mention related to death. Based on the Ullman concept about the factors that cause taboo, in Sundanese, the writer studied three factors, namely: 1) taboo of fear, 2) taboo of delicacy, and 3) taboo of profit. And the most dominant is caused by the taboo of fear. The habit of using euphemistic words is one of the applications of local wisdom values which do not express something directly (togmol). This is to refine and refine language. Therefore, this should be used as a literacy support, especially for future generations.
\end{abstract}

Keywords: language; taboo; euphemism; local wisdom; literacy

\section{Introduction}

Language and culture are interesting things to be studied by both language experts and people who have an interest in the field of language. There is a kind of relationship between the language produced by the speakers and their behavior in the real world, which is then called culture. Although not all of them are, there are some that are very related and interesting to study. As expressed by Wardaugh that there must be some kind of relationship between sounds, words, and language syntax and the way speakers of these languages experience the world and behave in it (Wardhaugh, 2006: 221). People's knowledge of language culture will provide provisions for him to communicate with fellow language users. Of course this is very important because sometimes misunderstandings in communication are caused by mistakes in understanding the culture where the language is located. For example, when the Sundanese say "butuh" in Sundanese culture it is not a problem because in Sundanese, "butuh" means "perlu (need)". However, when he said "butuh" in the Banjar community it would sound taboo. This is because in Banjar culture, the word "butuh" means male genitalia. Therefore, people outside Banjar replace the word "butuh" with the word "perlu".

One of the studies related to language and culture is the study of taboos and euphemisms. Every culture in society must have a taboo language which can then be tricked by the use of euphemisms so that the taboo language is disguised. So it is with Sundanese culture. In it you will find several taboo words which are certainly different from taboo words in other tribal cultures. Sundanese culture with the motto "Silih asah, silih asih, and silih asuh" has a concept of taboo that refers to this. In addition, the taboo language form in it is usually related to 
Sundanese local wisdom itself. So far, Sundanese local wisdom has its own characteristics and charm because it is known for its refinement and hospitality. This is of course very interesting to study. As stated by Suryalaga (in Jamaludin, 2011: 5) that in Sundanese culture, aesthetics does not stand alone, but is closely related to ethics. Ethics is a matter of measuring right and wrong, good and bad, related to manners and courtesy, morals, morals that are based on religious teachings. In its implementation, aesthetics is essentially used as a "container" and aesthetics is a "content". The content must be beneficial for the dignity of humanity, both personal and communal, while the wrapper or container must be beautiful in order to give birth to human sensory pleasure and inner and outer pleasure. Aesthetics is the language of taste, expressions that are created and received / responded to with taste through the senses. Aesthetics are not only denotative but also connotative. In Sundanese life, aesthetics is reflected not only in art but also in behavior and language. Beauty is related to taste (perception) which is related to the elements of time and conditions.

One of the unique concepts of Sundanese culture is the concept of "Panca Curiga". Panca means 5(five) and Curiga means eradication. According to Jojo Hamzah, a Sundanese cultural figure in Kuningan Regency, Panca Curiga is the language usually used to refine. The five suspicions include: Silib, Sindir, Simbul, Siloka, and Sasmita. Silib are forbidden words that are refined so that people do not go to a place, do not say something, or do not do something. Satire is the language used to gently admonish someone. Symbol is a feature or sign / icon about something. Siloka is a way of conveying something by means of presuppositions. As for sasmita, it is something that has to do with moods that are conveyed in different ways, for example when a parent scolds their child, it is not a hateful expression but an expression of affection. The linguistic taboo or word taboo is to avoid mentioning certain words and expressions in language is a common practice in every society (Mbaya, in Aliakbari, 2015: 91). According to Farb (1974: 91), any word is a collection of sounds that is not wrong until a community states that the word cannot be used in certain speech situations. That is what is called taboo.

In the same vein, Wardhaugh (2006: 238) asserts that some things are not said because people do not talk about them, and when these things are discussed, they are discussed in a very different way, namely subtly. He further noted that euphemistic words allow us to talk about unpleasant things to disguise or neutralize discomfort (Wardhaugh, 2006: 239). For example, in many societies, because death is feared, there are a number of euphemisms associated with this, such as the use of the word "pass away" to refine "die" or "mangkat" to refine the word "die". Thus it can be said that the concept of taboo and euphemism are two related things. Euphemism is an effort that can be made to avoid taboo words in a culture in society. (Sitaresmi, 2011). Linguistic taboos exist in all cultures of the world. According to Trudgill (in Aliakbari, 2015; 92), the most common taboo words in the world (especially those in English) are still related to sex and excretion. Apart from the similarity of language taboos among peoples, they also differ from culture to culture. Taboo is declared as a special culture, including the taboo deed in one culture does not necessarily apply in other cultures. In fact, this is the symbolic value that a culture gives a specific candidate to the words and expressions that make it taboo (Farb, 1974). Taboo can also change in time.

The subject of taboo can also differ greatly from culture to culture. However, they are usually things that include limbs and effluvia (sweat, mucus, face, menstrual fluid, etc.), sex organs and acts, defecation, disease, death, murder (including hunting and fishing), naming processes, holy creatures, objects and places, and so on (Allan and Burridge, in Aliakbari, 2015; 92). Regarding the subject of this taboo, Wardhaugh (2006: 239) states that the subject of taboo can vary widely. These include sex; Dead; expenditure of the body's metabolism; 
bodily functions; religious matters; and politics. Trudgill (in Mbaya, 2002: 224) states that taboo language is not only related to a lack of politeness. Often times, it is just a matter of convention where the normal use of goods in language is inhibited because of certain social values and beliefs. In line with Wardhaugh, Mbaya (2002: 225) states that in traditional Africa, taboo language refers to words for sex and body parts, words for death, marital relations and kinship, names of certain birds and animals, and so on.

Meanwhile, Ullman (in Wijana and Rohmadi, 2006: 111) states that based on psychological motivation, taboo words appear at least because of three things, namely the existence of something scary (taboo of fear), something that makes you feel bad (taboo of delicacy), and something immodest and inappropriate (taboo of propriety). The taboo of fear is anything that brings a frightening force and is believed to endanger life, is included in this taboo category. Likewise, the direct disclosure of the names of God and spirits is classified as the taboo of fear. For example, the Jews were forbidden from directly chanting the name of their Lord. For that they use another word that is parallel to the meaning of the word 'master' in English. In England and France, the words Lord and Seigneur are used respectively as a substitute for the word "Lord".

Taboo of delicacy is a human effort to avoid direct appointment of unpleasant things, such as various types of illness and death belonging to this second type of taboo. Euphemologically, the names of certain diseases are actually a form of euphemism which has lost its euphemistic nuance and is now closely related to taboo words. Taboo of propriety. This type of taboo relates to sex, certain body parts and their functions, as well as some swear words which are all inappropriate or indecent to express. In French, the mention of the word file in connection with 'daughter' still gets respect. However, when referring to a 'young woman' one should use the word jeune fille because the word fille itself is often used as a euphemistic form for 'whore'. Based on this explanation, the discussion about taboo and euphemism in Sundanese, especially Kuningan, cannot be separated from the local kerafilan values in it. Local wisdom values are synonymous with the stigma that Sundanese people are friendly and polite people, so they always use refinement in language. This needs to be considered and conveyed to future generations so that the values of goodness are not uprooted. One of the ways that can be used to instill the value of local wisdom is through the literacy movement.

Many studies discuss taboo language and euphemisms in a culture. For example, research on Taboo in Iran is written in the International Journal of Educational Investigations under the title A Sociolinguistic Study of Linguistic Taboos in the Iranian Society. The research was conducted by Mohammad Aliakbari and Hossein Raeesi from the Department of English Language, Ilam University, Iran. The paper examines language taboos in Iranian society, their relationship to the social context in which they are used, and the socio-cultural factors that influence their use. Using the general framework provided by Qanbar (2011) and adopting Brown and Levinson's $(1978,1987)$ politeness model as a theoretical basis for the analysis of taboo language, the paper describes the different categories of linguistic taboos in Iran's multiethnic society and the strategies employed by the Iranian speakers to avoid using such words. Includes using euphemistic words, Arabic equivalent words, constructs, substitutions, and loanwords with customized pronunciations. It also shows that some taboo languages need to be accompanied by fixed conventional words. These findings also make it clear that the concept of taboo language is based on Islamic cultural and religious norms. (Aliakbari, 2015: 1).

Subsequent research entitled Linguistic Taboo In African Marriage Context: A Study Of Oromo Laguu written by Maweja Mbaya from the University of Gaston Berger, Senegal. The 
paper, written in the Nordic Journal of African Studies, describes a custom in the Oromo (Ethiopian) culture known as "laguu" or "lagacha", which is a way of avoiding naming people who are married. Its topic deserves a lot of attention as an ethnolinguistic phenomenon in the culture mentioned above and which has not been written about so far. The study shows that because of taboo language, husbands, wives and in-laws avoid using each other's names and change some of their forms, most of which are imitations. This study analyzes taboo words and describes the mechanisms used to find substitutes (Mbaya, 2002: 224).

Next is a research entitled "A Sociolinguistic View of Linguistic Taboos And Euphemistic Strategies In The Algerian Society: Attitudes And Beliefs In Tlemcen Speech Community" written by Nadia Ghounane from the Department of Foreign Languages, Tlemcen University, Tlemcen, Algeria in the International Journal of Research in Applied, Natural and Social Sciences (IMPACT: IJRANSS). This research paper highlights the dark side of Algerian culture in relation to language use through investigation of taboo language and euphemistic usage. This shows that the attitudes of the Algerian speakers are related to certain sociocultural and psychological factors including social norms of society, social care of individuals and the social environment in which they relate in addition to their identity constructions and others.

Finally, a research written by Andrew Yau-hau Tse from the University of Malaysia Pahang entitled Linguistic Word Taboos in Chinese Culture in the British Journal of Humanities and Social Sciences. The aim of this study was to investigate the attitudes of Chinese society towards homophonic word taboos in Hong Kong. The questionnaire was distributed to seven groups of people, young and old, male and female, with questions relating to number four, which are phonetically related to the meaning of 'death' in Chinese culture. The findings reveal that older women are more superstitious than young students; There were no significant differences between older men and older women; Young male students and female students are relatively superstitious. To conclude, superstition is a social phenomenon and further research is needed to investigate the impact of the word taboo in different cultures. (Tse, 2011: 134-145)

Based on the explanation of previous research, the discussion in this paper is taboo language in Sundanese. The focus is on the realm where the word taboo is contained (the subject of taboo in Sundanese) and the form of euphemism used to avoid it. For this, the author will use the taboo concept presented by Wardhaugh. In addition, the writer will also analyze the triggering factors for the emergence of taboo language according to the theory presented by Ullman. Social phenomena that currently appear are shown by negative behaviors and symptoms that indicate the erosion of the character of a nation. This phenomenon can be seen in daily life at school and in the community that there are still many students who do deviant deeds. When viewed further, the degradation of the values and morals of Pancasila as the core of character formation has not only struck the younger generation, but has penetrated to community leaders, students, educators, political officials, even to the leaders of the nation and state.

\section{Method}

The research method used in the writing of this article is ethnographic research with observational data collection methods to collect data about taboo languages and interviews to 
ask expert opinions regarding the use of Taboo in Sundanese society. As for the object of research is the Sundanese language, especially in the Kuningan Regency, West Java.

\section{Result and Discussion}

The urgency of implementing character education in Budi Mulia International High School is because schools want to create students who are not only intelligent in their cognitive aspects, but also superior in their affective side. Seeing the challenges of the times that are increasingly alarming, many young people whose life patterns are not in line with the values and norms prevailing in society, and so that students are able to adapt to various changes that occur in the future and have a strong fortress not to engage in negative actions. As for the values of character education developed at Budi Mulia International High School, the implementation of character education is based on school philosophy, enforcement of rules at school, religious values and norms.

\subsection{The Subject of Taboo Language in Sundanese}

As previously stated, the subject of taboo language is usually related to sex, limbs, the process of excretion, things related to religion or belief (mention of animal names or other things that are considered sacred), and death. So it is with Sundanese. Usually, the taboo words contained in it are related to this. It is intended to correct the use of language with the aim of respecting, maintaining politeness, and not hurting. This is certainly in line with or in line with the motto in Sundanese culture, namely, penance, compassion, and care. Silih asah means reminding each other, chasing and respecting each other, and caring for each other means caring for each other. According to the Sundanese Kuningan crocodile, Jojo Hamzah, for the Sundanese the concepts of penance, compassion, and caring do not only apply to all humans. However, for all beings. Including animals, plants, and all things that exist in this world. With regard to this, the use of language is of great concern. Here are some words that are refined because they contain elements of taboo.

Table 1. Taboo Words Related to Belief or Religion and Mystical

\begin{tabular}{ll}
\hline \multicolumn{1}{c}{ Taboo Words } & \multicolumn{1}{c}{ Forms of Euphemism } \\
\hline Allah & gusti, pangeran \\
pare (rice) & Dewi sri \\
bumi (land) & ibu (mother) \\
langit (sky) & Bapa (father) \\
& aya nu karunyaeun (there are those who pity, usually the \\
Kasurupan (trance) & spirits of ancestors who have died) \\
jurig (ghost) & sandekala, lulun samak, uwil \\
tali puseur (umbilical cord) & Adi, dulur leutik (brother/ litle brother) \\
& Budak leutik ngambay peujit (a small child whose intestine \\
Jarum (needle) & was excreted \\
Budak leutik (litle boy/girll) & Kembang karang (Page flowers) \\
\hline
\end{tabular}

Table 2. Taboo Words Related to The Naming of Animals

\begin{tabular}{ll}
\hline Taboo Words & Forms of Euphemism \\
\hline Meong (cat) & Uwa (the name for uncle /older brother of mother or father) \\
Oray (snake) & Budug basu, gumarang
\end{tabular}




\begin{tabular}{ll} 
Lalay (bat) & Buah labu \\
Beurit (mouse ) & Neng Geulis (the name for beautyful girl) \\
Babi (wild boar) & Codol \\
\hline
\end{tabular}

Table 3. Taboo Words Related to Sex

\begin{tabular}{ll}
\hline Taboo Words & Forms of Euphemism \\
\hline Susu (breast) & pinareup \\
Heunceut (female genital) & kacang \\
Kanjut (male genital) & Siki, hulu \\
Bujur (butt) & imbit \\
Ngewe (making love) & sapatemon \\
\hline
\end{tabular}

Table 4. Words Related to The Secretion Process

\begin{tabular}{ll}
\hline Taboo words & Forms of euphemism \\
\hline Kakus (water closet) & jamban \\
Ngising (poop) & kabeuratan \\
Kiih (pee) & kahampangan \\
Mens (mentsruation) & kareseban \\
\hline
\end{tabular}

Table 5. Taboo Words Relating to Death

\begin{tabular}{ll}
\hline Taboo words & Forms of euphemism \\
\hline Paeh (died) & Ngantunkeun (leave) \\
\hline Nu paeh (people who have died) & Si jenat \\
\hline Dikubur (buried) & Dikureb \\
\hline Mayit (corpse) & layon \\
\hline
\end{tabular}

\subsection{Causes of The Emergence of Taboo in Sundanese}

Based on the theory about the factors causing the emergence of taboos expressed by Ullman, the factors causing the emergence of taboos are as follows.

\subsubsection{Taboo of fear}

This taboo is based on everything that brings fearful power and is believed to endanger life. It is included in the category of this type of taboo. In Sundanese language, which is included in this taboo are taboo words related to mystical beliefs / things and things that are related. with the mention of the names of the animals.

a. The word "mattressupan" is considered taboo when someone is possessed by a spirit (trance). So in a situation like that then used the uangkap "aya nu karunyaeun" which literally means "there is something (in this case spirits / ancestors) that feel sorry". This is intended so that the spirit who is possessing does not feel offended and immediately leaves the person who is being possessed.

b. The word "jurig" (ghost) and such as pocong, kuntilanak, genderewo is considered taboo to be pronounced at certain times, for example before sunset. Therefore, the word "sandekala" was used to refine it. It is said that the word is interpreted as "a spirit that comes out at a time of change, from noon to evening." Meanwhile the word "lulun samak" is usually used to refine the word "jurig" just before noon / noon.

c. The word "tali puseur" (umbilical cord) is usually smoothed into the word "adi" (younger brother) or "dulur" (brother) when a small child is sick. In Sundanese culture there is a custom that the cut umbilical cord is then inserted into a small bag made of cloth called "kuntung kundang". When young children were sick, ancient parents believed that the umbilical cord could be used as medicine. They usually mention: "Deukeutkeun jeung 
dulur na ambeh tereh waras" (Bring his brother close to get better soon). Then, the umbilical cord is put into the water and the water is drunk to the sick child. It is believed that it will help heal the child.

d. The word "jarum" (needle) was taboo at the time of arrival. To the extent that there is a myth that at nightfall we should not borrow "jarum" from other people. If we are forced to use a needle, we replace it with the phrase "budak leutik ngambay peujit". It is the siloka language for the word "jarum" at night in the hope that nothing harmful will happen.

e. In Sundanese there is a belief that at certain times there are bad people who roam around looking for little children, who are then called kidnappers. Usually before the month of Mulud or when there will be construction of roads, bridges, and others. Well, it is said that these little children will later be made sacrifices. At this time, parents usually refer to small children (budak leutik) with the expression "kembang karang". This is intended so that the kidnappers become obscure about the existence of small children in their environment so that their children will avoid being kidnapped.

f. The word "meong" which means cat is believed to have magical aya when we enter the forest. Therefore, there is a kind of belief that when you enter the forest you are not allowed to say the word. This is because it is feared that "meong gede" or tigers will appear. Therefore, when entering the forest, the word "meong" is replaced by the expression "uwa" which is a term for a male uncle / older brother of father or mother. It is said that the Sundanese pancakaki believe that cats are related to tigers, and their position is that cats are older than tigers.

g. The word "oray" (snake) is considered to have a taboo meaning when we enter certain / haunted areas because usually this animal is considered the incarnation of a devil or devil. So at that time, the word "oray" is better called the phrase "budug basu" or "gumarang"

$\mathrm{h}$. The word "Lalay" or bat is the same. This animal is considered the incarnation of a devil who usually delivers witcheraft or witcheraft. So if the night sees this animal, we call it the phrase "buah labu".

i. "Beurit" (rat) and "babi" (pig) are two animal pests that usually destroy agriculture. Now, when there is this animal, it is usually referred to as "neng geulis" for mice and "codol" for pigs to drive it away. This is so that the two beasts go away and do not destroy. The Sundanese believe that when animals are treated properly they will be good too.

\subsubsection{Taboo of delicacy}

Taboo of delicacy is a human effort to avoid direct exposure to unpleasant things, such as various types of illness and death. Examples of taboo words belonging to this type are as follows. The word "paeh" which means death is felt harsh so it is refined by the word "ngantunkeun" which means leaving the world. Meanwhile, the person who died "nu paeh" is refined by the word "si jenat" because the word is felt to be subtler and has more respect. Adapaun "mayit" which means the corpse is smoothed by the word "layon" and the word "buried" is refined by the word "dikureub / dikureubkeun".

\subsubsection{Taboo of profriety.}

Usually this type of taboo has to do with appropriateness in mentioning something usually related to sex, limbs and the exhaust system. In Sundanese the following words are taboos that fall into this category.

a. Words relating to limbs such as "susu" (breasts), "henceut" (female genitals), "kanjut" (male genitalia) and "bujur" (butt) were considered impolite and inappropriate when mentioned. in everyday life. Then the words were refined with "pinareup" for "susu", "kacang" for "henceut" "siki / hulu" for "kanjut" and "imbit" for "bujur". 
b. Even the word "ngewee" which means having sex is considered very rude / inappropriate when mentioned in public. Therefore, this word is refined by the word "sapatemon"

Those are some of the taboo words and euphemisms in Sundanese. All of them are based on the motto of "silih asah, silih asih, and silih asuh". This means that when we communicate using language with others we must pay attention to this motto. In order to create feelings of mutual respect and mutual care. Not only with fellow humans but with fellow beings in this world. It can be animals, plants, and astral creatures that are visible to the naked eye.

\subsection{Forms of Taboo and Euphemism as Local Wisdom to Support Literacy}

Taboo and euphemism in Kuningan is a form of local wisdom that must be preserved in the midst of the current era of globalization where the values in society are starting to be uprooted. As previously stated, Sundanese culture includes the mention of taboo words containing elements of the concept of silih asah sailih asih and silih asuh. This is of course a very valuable life value to be guarded in the midst of a life of individualism which is currently so thick in society. One of the efforts to incorporate local wisdom values is through the literacy movement in schools. Therefore, according to the writer, it is time for literacy teaching materials to include elements of local wisdom as their material.

\section{Conclusion}

Based on the explanation above, it can be concluded that the use of the word euphemism in language is intended to avoid taboo words that have been believed by Sundanese culture. These taboo words usually relate to beliefs / myths, mention of animal names, relate to organs and sex, and relate to death. The factors causing the emergence of taboo language were: 1 ) something that was frightening or considered threatening (taboo of fear); 2) something that is not wearing in mentioning something (taboo of delicacy); and 3) something that cannot be mentioned related to death (taboo of propriety). And among the three, there were more words in the taboo of fear category than the others. This form of taboo and euphoria is a local cultural heritage that must be introduced to the younger generation. Apart from being knowledge, of course this can teach them about the values prevailing in society. One of them is the value of politeness, which is very closely related to Sundanese culture, especially Kuningan. And one way to introduce it is to make it one of the materials in literacy.

\section{References}

[1] Aliakbari, Mohammad dan Hossein Raessi. 2015. "A Sociolinguistic Study of Linguistic Taboos in the Iranian Society". International Journal of Educational Investigations. 2 (3). 91-104.

[2] Farb, P. 1974. . Word Play: What Happens when People Talk. New York: Knopf.

[3] Ghounane, Nadia. 2014. "A Sociolinguistic View of Linguistic Taboos And Euphemistic Strategies In The Algerian Society: Attitudes And Beliefs In Tlemcen Speech Community". International Journal of Research in Applied, Natural and Social Sciences. 2 (3). 73-88

[4] Jamaludin. 2011. Beberapa Estetika dalam Budaya Sunda. [Online]. Tersedia:aresearch.upi.edu/.../pro_2011_fpbs_jamaludin_konsep_dasar_estetika_sunda.pdf[1 Juli 2017]

[5] Mbaya, Maweja. "Linguistic Taboo In African Marriage Context: A Study Of Oromo Laguu". Nordic Journal of African Studies. 11 (2): 224-235 
[6] Sitaresmi, Nunung, dan Mahmud Fasya. 2011. Pengantar Semantik Bahasa Indonesia. Bandung: UPI Press

[7] Tse, Andrew Yau-hau . 2011. "Linguistic Word Taboos in Chinese Culture". British Journal of Humanities and Social Sciences. 1 (2). 134-145

[8] Wardhaugh, Ronald. 2002. An Introduction To Sociolingustics. USA: Blackwell Publishing

[9] Wijana I Dewa Putu dan Muhammad Rohmadi. 2006. Sosiolinguistik: Kajian Teori dan Analisis. Yogyakarta: Pustaka Pelajar. 